\title{
PENGARUH SPACE DIVERSITY TERHADAP PENINGKATAN AVAILABILITY PADA JARINGAN MICROWAVE LINTAS LAUT DAN LINTAS PEGUNUNGAN
}

\section{THE INFLUENCE OF SPACE DIVERSITY ON INCREASING AVAILABILITY IN ACROSS THE SEA AND MOUNTAINS MICROWAVE NETWORKS}

\author{
Dekri Belly Liu ${ }^{1}$, Eka Wahyudi $^{2}$, Eka Setia Nugraha ${ }^{3}$ \\ 1, 2, 3 Fakultas Teknik Telekomunikasi \& Elektro, Institut Teknologi Telkom Purwokerto \\ 2' ekawahyudi@ittelkom-pwt.ac.id, ${ }^{3}$ eka_nugraha@ittelkom-pwt.ac.id
}

\begin{abstract}
Abstrak
Availability merupakan suatu parameter yang digunakan untuk mengetahui kehandalan sistem pada jaringan microwave. Namun ada kalanya availability yang dihasilkan dalam perancangan sistem tidak optimal, maka perlu dilakukan optimasi. Optimasi dapat dilakukan dengan menggunakan teknik space diversity, di mana akan dilakukan penambahan antena diversity utuk melakukan optimasinya. Penelitian ini bertujuan untuk mengetahui peningkatan availability yang paling signifikan dari beberapa kondisi jaringan, yaitu berlokasi di atas laut dan daerah pegunungan. Data yang dipergunakan diperoleh dengan melakukan studi kasus pada PT. Alita Praya Mitra, sedangkan untuk melakukan simulasi perancangan jaringan menggunakan aplikasi perangkat lunak Pathloss 5.0. Jaringan yang berada di Laut menghasilkan peningkatan availability yang lebih tinggi dari pada jaringan yang berada di pegunungan. Peningkatan availability jaringan di laut yaitu $0,961446 \%$, sedangkan peningkatan availability jaringan di pegunungan yaitu $0,060623475 \%$. Hal tersebut dikarenakan pengaruh oleh terrain roughness, climatic factor dan $\mathrm{C}$ factor. Nilai terrain roughness jaringan laut yaitu 6,10 meter, sedangkan jaringan di pegunungan yaitu 32,10 meter. Kemudian climatic factor jaringan laut bernilai 2 sedangkan jaringan pegunungan bernilai 0,25. Semakin kecil nilai terrain roughness dan semakin besar nilai climatic factor mengakibatkan nilai $\mathrm{C}$ factor meningkat. Nilai $\mathrm{C}$ factor jaringan laut yaitu 6,56 sedangkan jaringan di pegunungan yaitu 0,1 .
\end{abstract}

Kata kunci : Space diversity, Microwave, Availability

\begin{abstract}
Availability is a parameter used to determine the reliability of systems on microwave networks. But there are condition when the availability generated in system design is not optimal, therefore need to be optimized. Optimization can be done by using space diversity technique, where will be done the addition of antenna diversity to do the optimization. Research aims to determine the availability of the most significant of some network conditions, that located above the sea and located in the mountains. The data used is obtained by doing case study at PT. Alita Praya Mitra, while to simulate network design using Pathloss 5.0 software application. Networks in the Sea result in increased availability higher than those in the mountains. The increase of network availability in the sea is $0.961446 \%$, while the increase in network availability in the mountains is $0.060623475 \%$. This is due to the influence of terrain roughness, climatic factor and $\mathrm{C}$ factor. Terrain roughness value of marine tissue is 6.10 meters, while the network in the mountains is 32.10 meters. Then the climatic factor of the marine network is worth 2 while the mountain network is worth 0.25 . Then the value of $\mathrm{C}$ factor of sea tissue is 6.56 while the network in the mountains is 0.1 .
\end{abstract}

Keywords: Space diversity, Microwave, Availability 


\section{PENDAHULUAN}

Pertukaran informasi merupakan kebutuhan pokok pada masa sekarang, dikarenakan kebutuhan untuk mendapatkan berbagai informasi sangatlah tinggi. Pertukaran informasi tersebut tidak terlepas dari peran teknologi telekomunikasi, yang berperan dalam mengirimkan informasi dari jarak yang jauh. Teknologi telekomunikasi memiliki 2 jenis yaitu secara wireline atau wireless. Untuk teknologi wireline sendiri merupakan teknologi yang menggunakan media kabel/fisik untuk mentransmisikan datanya. Sedangkan teknologi wireless menggunakan udara/ruang hampa sebagai media untuk mentransmisikan data.

Teknologi komunikasi radio gelombang mikro menggunakan microwave dan antenna untuk memancarkan sinyal yang digunakan untuk berkomunikasi. Sinyal tersebut dipancarkan melalui medium udara. Penggunaan udara sebagai media transmisi pada sistem komunikasi radio gelombang mikro tentunya memiliki kelebihan dan kekurangannya.

Kelebihan penggunaan udara sebagai media transmisi yaitu menghemat biaya yang dikeluarkan, di mana jika menggunakan kabel dalam radius puluhan kilometer maka akan mengeluarkan biaya yang besar. Kemudian kekurangannya yaitu loss transmisi yang didapatkan lebih besar dari pada penggunaan wireline. Selain itu penggunaan wireless pada jaringan komunikasi juga memerlukan syarat terjadinya Line Of Sight (LOS) antar kedua site, oleh karena itu jika terdapat obstacle yang mengganggu LOS antar site maka kualitas jaringan akan terganggu pula. Berbeda halnya dengan jaringan wireline yang tidak memerlukan Line Of Sight (LOS) untuk mengkoneksikan site satu dengan yang lainnya.

Kehandalan sistem atau yang biasa disebut dengan availability merupakan ukuran kehandalan suatu sistem. Dengan melihat nilai availability-nya, maka dapat diketahui suatu sistem dalam kondisi yang optimal atau tidak. Secara ideal availability sistem harus $100 \%$, namun hal tersebut tidak mungkin terpenuhi dikarenakan terdapat loss yang terjadi. Terlalu besarnya loss yang terjadi mengakibatkan sistem menjadi tidak handal. Unavailability merupakan ketidakhandalan sistem dalam memberikan pelayanan. Semakin besarnya nilai unavailability sistem, maka semakin buruknya kualitas dalam pemberian layanannya oleh sistem tersebut.

Oleh karena itu, diperlukan adanya optimasi yang dilakukan untuk meningkatkan availability sistem komunikasi radio microwave. Teknik diversity merupakan suatu cara yang digunakan mengoptimalkan jaringan microwave. Terdapat 2 jenis teknik diversity yang digunakan yaitu teknik space diversity dan teknik frequency diversity. Teknik space diversity merupakan teknik untuk mengoptimalkan jaringan microwave dengan menambahkan antena diversity disetiap site-nya. Kemudian teknik frequency diversity menggunakan lebih dari satu frekuensi pada antena yang sama.

Dalam penelitian ini, akan dibuat perancangan jaringan microwave, di mana jaringannya berada pada lokasi yang berbeda dan masing-masing terdiri dari 2 link hop. Namun kedua jaringan tersebut memiliki frekuensi dan perangkat yang sama. Lokasi jaringan pertama berada di atas permukaan laut dan lokasi jaringan kedua berada di pegunungan. Kemudian jaringan tersebut akan dioptimasi menggunakan teknik space diversity. Hal ini dilakukan karena dalam kondisi jaringan tanpa diversity, kehandalan (availaibility) dari jaringan masih di bawah nilai 99,99\%, sehingga masih kurang layak dan diperlukan optimasi. Rendahnya nilai availability tersebut disebabkan karena dengan menggunakan antena tunggal, maka penerimaan sinyal belum maksimal untuk mengatasi dampak dari fluktuasi penerimaan daya (fading), mengingat kondisi geografis dari kedua jaringan tersebut berada pada lingkungan yang berkategori ekstrim (pegunungan dan laut). Dengan menggunakan teknik space diversity, maka akan terdapat penambahan antena diversity yang fungsinya untuk menangkap pancaran sinyal dari sisi transmitter, sehingga daya sinyal yang 
diterima akan lebih besar. Semakin besar daya sinyal yang diterima, maka availability akan meningkat. Hal ini telah dibuktikan pada penelitian sebelumnya bahwa dengan teknik space diversity, mampu meningkatkan nilai availability dengan nilai di atas $99,99 \% .^{[1-3]}$

\section{DASAR TEORI DAN METODOLOGI}

Komunikasi gelombang mikro (microwave) merupakan suatu teknik dalam mentransmisikan informasi dari suatu tempat ke tempat lain tanpa adanya interupsi sampai ke penerima dengan menggunakan gelombang. ${ }^{[4]}$ Sistem Komunikasi Microwave terdiri atas dua bagian yaitu pemancar (transmitter) dan penerima (receiver). Dalam Perjalanannya dari antenna pemancar ke antenna penerima, gelombang radio melalui berbagai lintasan dengan beberapa mekanisme perambatan dasar. Mekanisme perambatan tersebut adalah Line of sight (LOS) merupakan lintasan gelombang radio yang mengikuti garis pandang yang berarti bahwa antara antena pemancar dan antena penerima tidak ada penghalang (obstacle), yang menghalangi lintasan perambatan gelombang mikro, seperti ditunjukkan pada Gambar 1 yang merupakan propagasi Line of sight (LOS). ${ }^{[5]}$

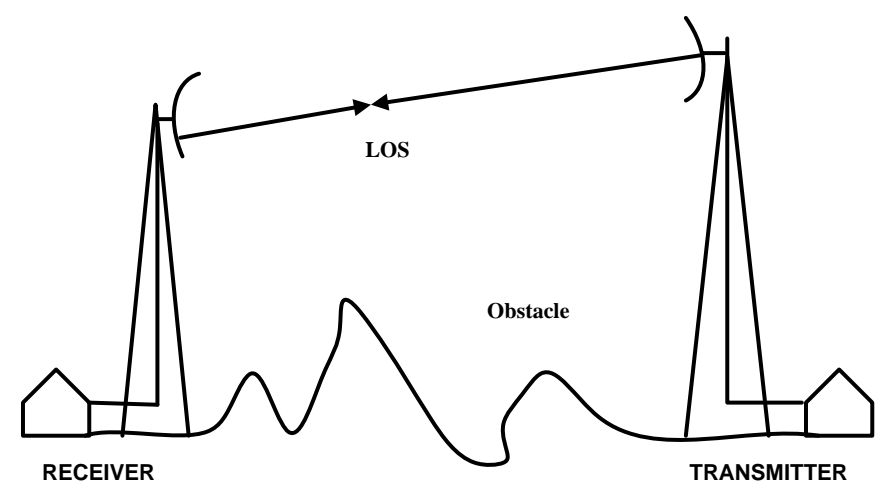

Gambar 1. Propagasi LOS

\subsection{Penanunggulangan Fading}

Terdapat banyak pengaruh redaman dan fading pada berkas gelombang mikro, oleh karena itu perlu diberikan suatu solusi untuk mengatasinya yaitu dengan peragaman (diversity). Diversity adalah suatu teknologi yang diterapkan pada penerimaan sistem komunikasi yang pada dasarnya untuk mengatasi pengaruh fading yang terjadi pada lintasan jalur komunikasi microwave dan operasi sistem ini dilakukan oleh dua atau lebih pada sistem secara bersamaan untuk meningkatkan kualitas sinyal yang diterima. Contoh teknik diversity yaitu space diversity dan frequency diversity. Teknik ini dapat dijelaskan sebagai peralatan yang bersifat redundancy, yaitu jalur jaringan alternatif atau cadangan yang digunakan untuk meningkatkan ketersediaan jaringan sehingga jika dalam suatu jaringan terdapat Link yang terputus maka jalur tersebut masih bisa terhubung tanpa mempengaruhi konektivitas perangkat pada jalur tersebut. Dengan demikian fading dapat diatasi dengan cara sebagai berikut:

\subsubsection{Space Diversity}

Penerima dari radio gelombang mikro menerima sinyal dari dua atau lebih antena yang terpisah secara vertikal atau menggunakan beberapa receiver yang umumnya dua sistem dengan antenanya yang diletakkan terpisah secara vertikal dalam jarak beberapa panjang gelombang $(\lambda)$ satu sama lain. Oleh karena dimensinya adalah jarak, maka dikatakan sebagai jenis teknik space diversity atau peragaman ruang. Setelah sinyal diterima oleh masing-masing antena kemudian 
secara simultan akan dihubungkan ke diversity combiner untuk menggabungkan sinyal yang diterima oleh antena penerima. Konfigurasi space diversity ditunjukkan Gambar 2.

Sistem transmisi menggunakan teknik space diversity untuk mengatasi fading akan diperoleh faktor perbaikan dengan persamaan $(1):^{[2-3,6]}$

$$
I_{S D}=1,2 \times 10^{-3} \times \frac{\mathrm{f}}{\mathrm{D}} x \mathrm{~s}^{2} \times \mathrm{v}^{2} \times 10^{\frac{\mathrm{A}}{10}}
$$

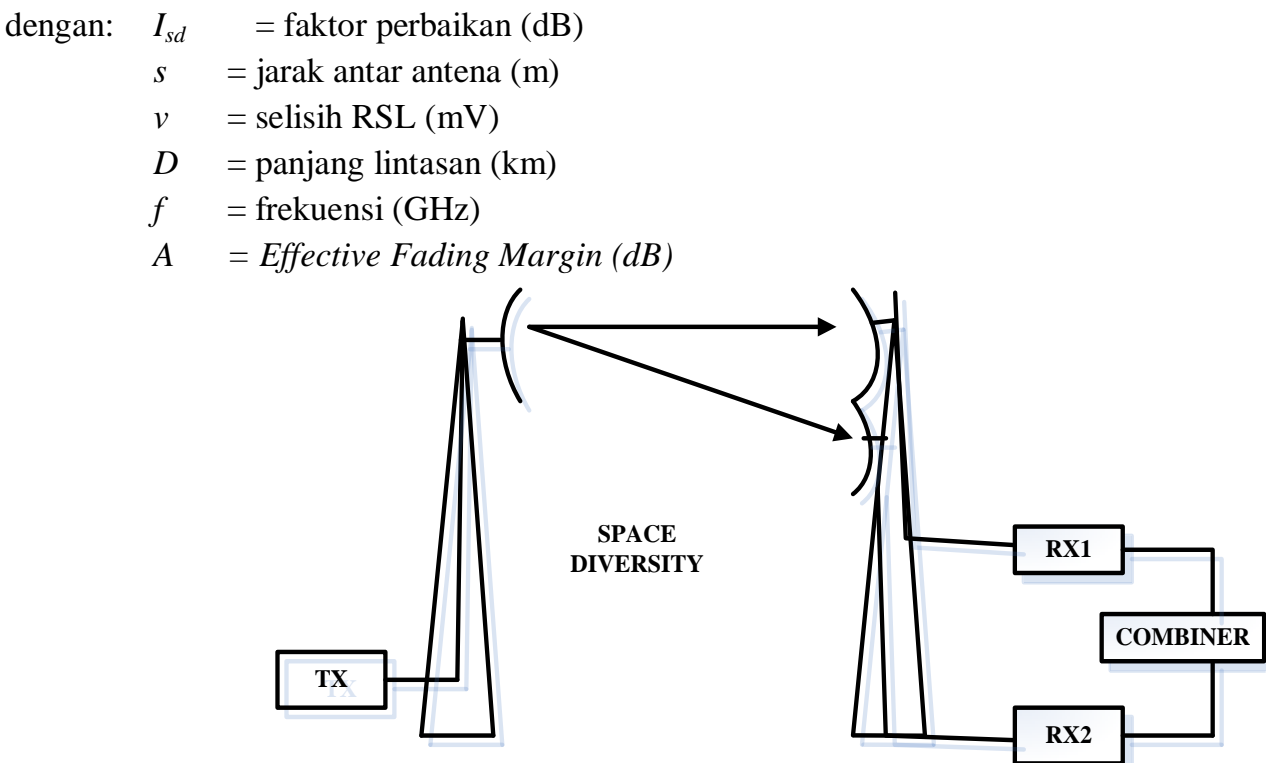

Gambar 2. Sistem Space Diversity

\subsubsection{Frequency Diversity}

Frequency Diversity seperti yang ditunjukan pada Gambar 3 merupakan sistem yang mengoperasikan dua frekuensi gelombang mikro pada satu antena baik itu di pemancar maupun penerima. Informasi yang dikirimkan secara simultan dikirimkan kedua transmitter yang beroperasi pada frekuensi yang berbeda kemudian diteruskan ke satu antena pemancar. Pada antena penerima akan dikumpulkan informasi dan memisahkannya menjadi dua sinyal. Sistem frequency diversity tertampil pada Gambar 3. ${ }^{[7-8]}$

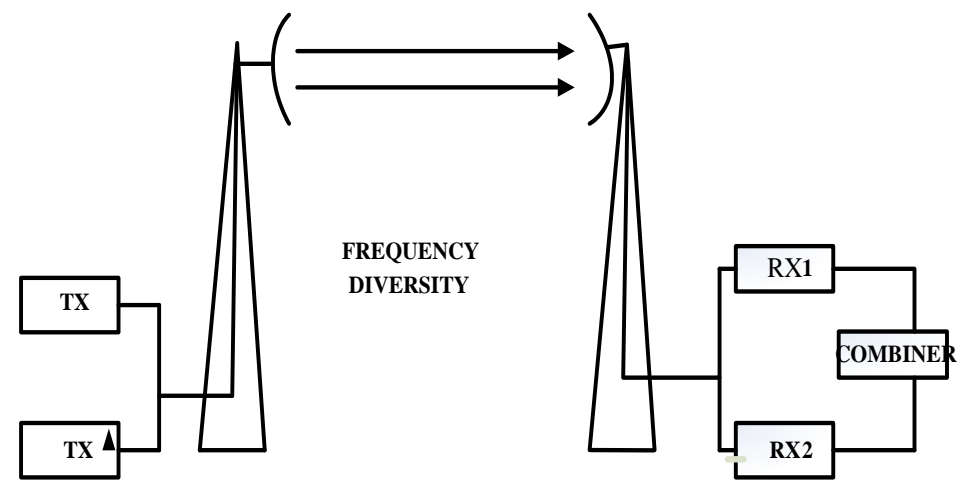

Gambar 3. Sistem Frequency Diversity 


\subsection{Path Loss}

Path loss adalah pengurangan densitas daya (atenuasi) dari gelombang elektromagnetik seperti merambat melalui ruang. Path loss merupakan komponen utama dalam analisis dan desain link budget sistem telekomunikasi. Istilah ini umumnya digunakan dalam komunikasi nirkabel dan propagasi sinyal. Path loss terjadi disebabkan karena banyak faktor, seperti hilangnya ruang bebas, refraksi, difraksi, refleksi, aperture menengah rugi kopling, dan penyerapan. Path loss juga dipengaruhi oleh kontur medan, lingkungan (perkotaan atau pedesaan, vegetasi dan dedaunan), media propagasi (udara kering atau lembab), jarak antara pemancar dan penerima, dan tinggi dan lokasi antena. Path loss biasanya mencakup kerugian propagasi disebabkan oleh perluasan alami dari depan gelombang radio di ruang bebas (yang biasanya mengambil bentuk sebuah bola yang terus meningkat), kerugian penyerapan (kerugian kadang-kadang disebut penetrasi), ketika sinyal melewati media yang tidak transparan untuk gelombang elektromagnetik, kerugian difraksi ketika bagian dari gelombang radio depan halangan buram, dan kerugian yang disebabkan oleh fenomena lain. ${ }^{[9-10]}$

\subsection{Metodologi}

Metodologi penelitian yang dilakukan pada penelitian ini dengan melakukan studi kasus PT. Alita Praya Mitra yang belokasi di Jakarta Selatan. Di lokasi tersebut dilakukan proses pengumpulan data yang sesuai dengan materi dan objek penelitian untuk melengkapi materi penelitian, yaitu berupa data longitude, latitude, frekuensi, tinggi perangkat dan spesifikasi perangkat yang dipergunakan pada kedua link hop. Sedangkan dalam membuat perencanaan, dipergunakan aplikasi perangkat lunak Pathloss 5.0 dengan menggunakan frekuensi sebesar sebesar $8 \mathrm{GHz}$ untuk mendapatkan parameter hasil simulasi seperti received signal level, availability, unavailability dan fading margin akibat multipath. Setelah itu akan dilakukan pengamatan dari hasil optimasi performansi jaringan yang dibuat. Tujuannya yaitu mengamati pengaruh kondisi jaringan terhadap peningkatan nilai availability. Kondisi jaringan yang dimaksud yaitu seperti tingkat kekasaran bumi (terrain roughness), faktor iklim (climatic factor) dan jarak antar (C factor). Untuk dukungan referensi, maka dasar teori didapatkan melalui berbagai referensi, baik dari buku, jurnal dan internet.

\section{PEMBAHASAN}

Data yang digunakan dalam perancangan jaringan microwave tertampil seperti pada Tabel 1. yang mencakup koordinat lokasi, ketinggian tanah dan tinggi menara. Untuk spesisikasi antena utama dan antena diversity mempergunakan model PL4-77GD yang memiliki diameter 1,2 meter dan gain sebesar 37,2 dB. Untuk sistem Tx - Rx mempergunakan model IPASO IHG 8GHz 128Q $160 \mathrm{M}$ yang memiliki Tx Power sebesar $26 \mathrm{dBm}$, bit rate $160 \mathrm{Mbps}$, Bit Error Rate (BER) sebesar $10^{-6}$ dan Rx Threshold Level sebesar $-72 \mathrm{dBm}$. Untuk jaringan pertama terdapat tiga buah site yaitu Muarabinuangeun, Panggarangan, dan Bayah Barat. Kemudian jaringan kedua juga terdapat tiga buah site yaitu Cigoong Utara, dan Gunung Kencana, dan Muarabinuangeun.

Tabel 1. Data Site Jaringan Pertama

\begin{tabular}{|l|r|r|r|}
\hline \multicolumn{1}{|c|}{ Site A } & Muara Binuangeun & Panggarangan & \multicolumn{1}{c|}{ Bayah Barat } \\
\hline Latitude & $064959,40 \mathrm{~S}$ & $065404,88 \mathrm{~S}$ & $065605,21 \mathrm{~S}$ \\
Longitude & $1055325,78 \mathrm{E}$ & $1060903,98 \mathrm{E}$ & $1061449,41 \mathrm{E}$ \\
Elevation & $16,7 \mathrm{~m}$ & $6,9 \mathrm{~m}$ & $7,5 \mathrm{~m}$ \\
Tower height & $40,0 \mathrm{~m}$ & $71,0 \mathrm{~m}$ & $51,0 \mathrm{~m}$ \\
\hline
\end{tabular}


Jurnal Elektro Telekomunikasi Terapan Desember 2017

\begin{tabular}{|l|r|r|r|}
\hline \multicolumn{1}{|c|}{ Site B } & Cigoong Utara & Gunung Kencana & \multicolumn{1}{c|}{ Muarabinuangeun } \\
\hline Latitude & $062422,38 \mathrm{~S}$ & $063444,19 \mathrm{~S}$ & $064959,40 \mathrm{~S}$ \\
Longitude & $1061000,41 \mathrm{E}$ & $1060431,29 \mathrm{E}$ & $1055325,78 \mathrm{E}$ \\
Elevation & $50,8 \mathrm{~m}$ & $349,1 \mathrm{~m}$ & $16,7 \mathrm{~m}$ \\
Tower height & $50,0 \mathrm{~m}$ & $52,0 \mathrm{~m}$ & $40,0 \mathrm{~m}$ \\
\hline
\end{tabular}

Dari data site Tabel 1, setelah diolah menggunakan aplikasi pathloss 5.0 maka jaringan pertama akan terlihat seperti Gambar 4, di mana link hop yang terbentuk merupakan jaringan yang melintasi lautan (dataran rendah) dengan mempergunakan satu pengulang (hop repeater) dan untuk jaringan kedua terlihat seperti pada Gambar 5, di mana link hop yang terbentuk merupakan jaringan yang melintasi perbukitan (dataran tinggi) yang juga dengan mempergunakan satu pengulang (hop repeater).

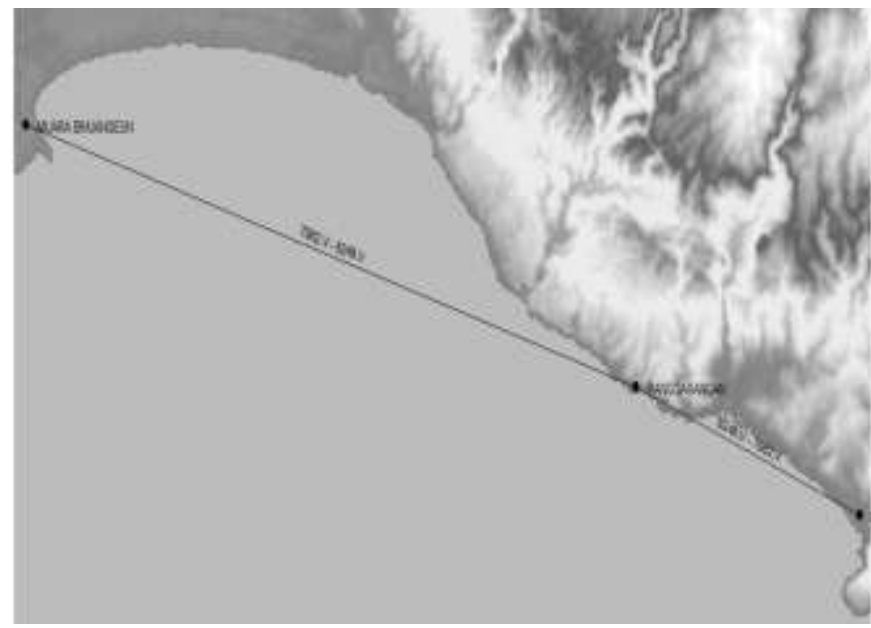

Gambar 4. Tampilan Jaringan Pertama

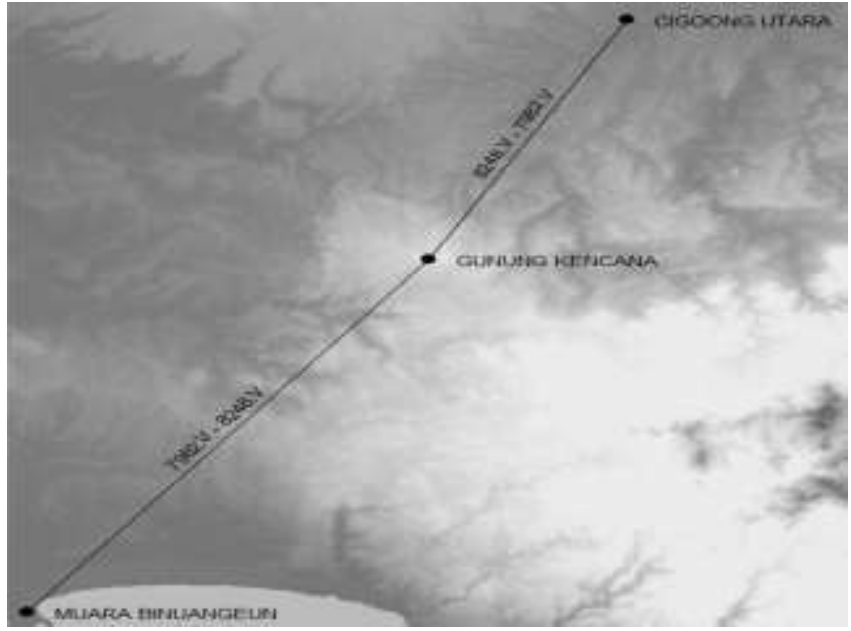

Gambar 5. Tampilan Jaringan Kedua

Tabel 2 menampilkan parameter-parameter yang diamati untuk mengetahui pengaruh kondisi jaringan terhadap peningkatan availability. Link hop pertama memiliki jarak yang lebih jauh dibandingkan dengan link hop kedua. Hal tersebut mengakibatkan nilai FSL link hop pertama lebih besar dari pada link hop kedua. Karena FSL link hop pertama lebih besar dari pada link hop kedua, 
maka RSL yang dapatkan sebelum dan setelah optimasi link hop pertama jauh lebih kecil dari link hop kedua.

Tabel 2. Hasil Perhitungan Jaringan Pertama

\begin{tabular}{|c|c|c|c|c|}
\hline \multirow[t]{2}{*}{ Parameter } & \multicolumn{2}{|c|}{$\begin{array}{c}\text { Muara Binangeun - Panggarangan } \\
\text { (Link hop pertama) }\end{array}$} & \multicolumn{2}{|c|}{$\begin{array}{c}\text { Panggarangan - Bayah Barat (Link } \\
\text { hop kedua) }\end{array}$} \\
\hline & Sebelum Optimasi & Sesudah Optimasi & Sebelum Optimasi & Sesudah Optimasi \\
\hline $\operatorname{Jarak}(\mathrm{Km})$ & \multicolumn{2}{|c|}{$29,78 \mathrm{Km}$} & \multicolumn{2}{|c|}{$11,23 \mathrm{Km}$} \\
\hline FSL (dB) & \multicolumn{2}{|c|}{$139,99 \mathrm{~dB}$} & \multicolumn{2}{|c|}{$131,51 \mathrm{~dB}$} \\
\hline $\operatorname{RSL}(\mathrm{dBm})$ & $-55,61$ & $-52,05$ & $-46,93$ & $-43,39$ \\
\hline C Factor & \multicolumn{2}{|c|}{6,56} & \multicolumn{2}{|c|}{6,56} \\
\hline Terrain Rougness (m) & \multicolumn{2}{|c|}{6,10 meter } & \multicolumn{2}{|c|}{6,10 meter } \\
\hline Climatic Factor & \multicolumn{2}{|c|}{2} & \multicolumn{2}{|c|}{2} \\
\hline Fading Margin $(\mathrm{dB})$ & \multicolumn{2}{|c|}{1239,483} & \multicolumn{2}{|c|}{9928,352} \\
\hline Improvement Factor & $16,38 \mathrm{~dB}$ & $19,94 \mathrm{~dB}$ & $25,05 \mathrm{~dB}$ & $28,60 \mathrm{~dB}$ \\
\hline Unavailability (\%) & 1,9104611 & 0,001541336 & 0,013912767 & 0,0000006187 \\
\hline$\Delta$ Unavailability $(\%)$ & \multicolumn{2}{|c|}{$1,90892 \%$} & \multicolumn{2}{|c|}{$0,013912149 \%$} \\
\hline Availability (\%) & 98,08953887 & 99,99845866 & 99,98608723 & 99,99999938 \\
\hline$\Delta$ Availability $(\%)$ & \multicolumn{2}{|c|}{$1,90892 \%$} & \multicolumn{2}{|c|}{$0,013912149 \%$. } \\
\hline
\end{tabular}

Perbedaan RSL tersebut mengakibatkan perbedaan pada fading margin-nya pula. Karena fading margin dipengaruhi oleh RSL. Selain itu, fading margin juga dipengaruhi oleh C factor. C factor pada jaringan pertama memiliki nilai yang sama untuk kedua site-nya yaitu sebesar 6,58. Nilai C factor dipengaruhi oleh terrain rougness dan climatic factor. Untuk jaringan pertama memiliki nilai climatic factor-nya 2 dan terrain rougness-nya 6,10 meter. Nilai 2 pada climatic factor merupakan faktor iklim pada daerah laut dan terrain rougness 6,10 menandakan jaringan berada pada dataran yang sangat rendah.

Fading margin Link hop pertama sebelum optimasi yaitu $16,38 \mathrm{~dB}$, jauh lebih kecil dibandingkan fading margin link hop kedua yaitu 25,05 dB. Karena fading margin link hop pertama lebih kecil dari link hop kedua, maka unavailability sebelum optimasi yang didapatkan lebih besar dari link hop kedua. Unavailability link hop pertama sebelum optimasi yaitu $1,9104611 \%$, dan link hop kedua 0,013912767\%.

Tabel 3. Hasil Perhitungan Jaringan Kedua

\begin{tabular}{|c|c|c|c|c|}
\hline \multirow[t]{2}{*}{ Parameter } & \multicolumn{2}{|c|}{$\begin{array}{c}\text { Cigoong Utara - Gunung Kencana } \\
\text { (Link hop pertama) }\end{array}$} & \multicolumn{2}{|c|}{$\begin{array}{c}\text { Gunung Kencana - Muara Binuangeun } \\
\text { (Link hop kedua) }\end{array}$} \\
\hline & Sebelum Optimasi & Sesudah Optimasi & Sebelum Optimasi & Sesudah Optimasi \\
\hline $\operatorname{Jarak}(\mathrm{Km})$ & \multicolumn{2}{|c|}{21,62} & \multicolumn{2}{|c|}{34,76} \\
\hline FSL (dB) & \multicolumn{2}{|c|}{137,2} & \multicolumn{2}{|c|}{141,33} \\
\hline $\operatorname{RSL}(\mathrm{dBm})$ & $-52,74$ & $-49,19$ & -57 & $-53,45$ \\
\hline C Factor & \multicolumn{2}{|c|}{0,1} & \multicolumn{2}{|c|}{0,1} \\
\hline Terrain Rougness (m) & \multicolumn{2}{|c|}{31,53} & \multicolumn{2}{|c|}{32,06} \\
\hline Climatic Factor & \multicolumn{2}{|c|}{0,25} & \multicolumn{2}{|c|}{0,25} \\
\hline Fading Margin $(\mathrm{dB})$ & 19,25 & 22,8 & 14,99 & 18,54 \\
\hline Improvement Factor & \multicolumn{2}{|c|}{3016,149} & \multicolumn{2}{|c|}{7027,172} \\
\hline
\end{tabular}


Jurnal Elektro Telekomunikasi Terapan Desember 2017

\begin{tabular}{|l|c|c|c|c|}
\hline Unavailability (\%) & 0,005752933 & 0,0000019738 & 0,000638278 & 0,0000009083 \\
\hline$\Delta$ Unavailability (\%) & \multicolumn{2}{|c|}{0,005751026} & \multicolumn{2}{c|}{0,06373695} \\
\hline Availability (\%) & 99,99424707 & 99,99999809 & 99,9361722 & 99,99990917 \\
\hline$\Delta$ Availability (\%) & \multicolumn{2}{|c|}{0,005751026} & \multicolumn{2}{c|}{0,06373695} \\
\hline
\end{tabular}

Setelah dioptimasi menggunakan teknik space diversity, terdapat penurunan unavailability. Pada link hop pertama setelah dioptimasi menghasilkan unavailability sebesar 0,001541336\%, sehingga terjadi penurunan sebesar 1,90892\%. Kemudian pada link hop kedua setelah dioptimasi menghasilkan unavailability sebesar $0,0000006187 \%$, sehingga mengalami penurunan unavailability sebesar $0,013912149 \%$. Besarnya peningkatan availability sama dengan besarnya penurunan unavailability.

Tabel 3 menampilkan parameter-parameter yang diamati untuk mengetahui pengaruh kondisi jaringan terhadap peningkatan availability pada jaringan kedua. Kondisi jaringan kedua yaitu memiliki terrain rougness yang besar yaitu 31,53 meter untuk link hop pertama dan 32,06 meter untuk link hop kedua. Hal tersebut dikarenakan jaringan kedua berlokasi di pegunungan. Karena jaringan kedua dipegunungan, maka nilai climatic factor yang digunakan yaitu 0,25 . Nilai $\mathrm{C}$ factor yang terhitung yaitu 0,1 . Hal tersebut mengindikasikan bahwa kondisi jaringan yang digunakan memiliki kondisi propagasi sinyal yang baik.

Jarak link hop pertama lebih pendek dibandikan jarak link hop kedua. Oleh karena itu nilai FSL Link hop pertama lebih kecil dibanding link hop kedua. Nilai FSL berpengaruh pada nilai RSL. Nilai FSL yang lebih kecil akan menghasilkan RSL yang lebih besar dan sebaliknya. RSL yang dihasilkan sebelum dan sesudah optimasi pada link hop pertama lebih besar dibanding dengan link hop kedua, perbedaan RSL tersebut berpengaruh pada nilai fade margin-nya.

Fading margin link hop pertama sebelum optimasi yaitu 19,25 dB, jauh lebih besar dibandingkan fading margin link hop kedua yaitu 14,99 dB. Karena fading margin link hop pertama lebih besar dari link hop kedua, maka unavailability sebelum optimasi yang didapatkan lebih kecil dari link hop kedua.

Setelah dioptimasi menggunakan teknik space diversity, terdapat peningkatan availability. Pada link hop pertama setelah dioptimasi mendapatkan availability sebesar 99,99999809\%, sehingga terjadi peningkatan sebesar $0,005751026 \%$. Kemudian pada link hop kedua setelah dioptimasi mendapatkan availability sebesar 99,99990917\%, sehingga mengalami peningkatan availability sebesar $0,06373695 \%$.

Pada Tabel 4 dan Tabel 5 menampilkan peningkatan availability kedua jaringan microwave. Rata-rata peningkata availability jaringan pertama yaitu 0,961446\%. Sedangkan rata-rata peningkatan availability jaringan kedua yaitu 0,060623475\%.

Tabel 4. Peningkatan Availability Jaringan Pertama

\begin{tabular}{|l|l|r|}
\hline \multicolumn{1}{|c|}{ Site } & \multicolumn{1}{c|}{ Report } & Availability (\%) \\
\hline $\begin{array}{l}\text { Muara Binuangeun - } \\
\text { Panggarangan }\end{array}$ & Sebelum Optimasi & 98,08953887 \\
\cline { 2 - 3 } & Sesudah Optimasi & 99,99845866 \\
\hline Peningkatan Link hop 1 & 1,90892 \\
\hline $\begin{array}{l}\text { Panggarangan - } \\
\text { Bayah Barat }\end{array}$ & Sebelum Optimasi & 99,98608723 \\
\cline { 2 - 3 } & Sesudah Optimasi & 99,99999938 \\
\hline \multicolumn{2}{|l}{ Peningkatan Link hop 2} & 0,013912149 \\
\hline
\end{tabular}




\begin{tabular}{|l|r|}
\hline Peningkatan Availability Jaringan & 0,961446 \\
\hline
\end{tabular}

Tabel 5. Peningkatan Availability Jaringan Kedua

\begin{tabular}{|l|l|r|}
\hline \multicolumn{1}{|c|}{ Site } & \multicolumn{1}{c|}{ Report } & Availability (\%) \\
\hline $\begin{array}{l}\text { Cigoong Utara }- \\
\text { Gunung Kencana }\end{array}$ & Sebelum Optimasi & 99,99424707 \\
\cline { 2 - 3 } & Sesudah Optimasi & 99,99999809 \\
\hline Peningkatan Link hop 1 & 0,005751 \\
\hline $\begin{array}{l}\text { Gunung Kencana - } \\
\text { Muara Binuangeun }\end{array}$ & Sebelum Optimasi & 99,9361722 \\
\cline { 2 - 3 } & Sesudah Optimasi & 99,999990917 \\
\hline Peningkatan Link hop 2 & 0,06373695 \\
\hline Peningkatan Availability Jaringan & 0,060623475 \\
\hline
\end{tabular}

\section{KESIMPULAN}

Berdasarkan analisis jaringan transmisi Microwave dapat diambil kesimpulan sebagai berikut:

1. Semakin jauh jarak antar site BTS, maka availability yangdidapatkan semakin rendah dan sebaliknya. Contohnya pada jaringan di area laut link hop pertama yang memiliki jarak antar site 29,78 Km mendapatkan availability 98,08953887\%. Sedangkan pada link hop kedua yang memiliki jarak antar site 11,23 Km mendapatkan availability 99,98608723\%.

2. Terrain rougness yang besar pada jaringan microwave menyebabkan unavailability yang didapatkan kecil. Contohnya pada jaringan di pegunungan link hop pertama memiliki terrain roughness $32 \mathrm{~m}$, sedangkan pada jaringan di laut link hop pertama memiliki terrain roughness $6,10 \mathrm{~m}$. Unavailability jaringan di pegunungan yaitu $0,005752933 \%$ sedangkan jaringan di laut menghasilkan 1,90892\%.

3. Jaringan yang berlokasi di atas laut memiliki nilai climatic factor 2 dan jaringan yang berlokasi di pegunungan memiliki nilai climatic factor 0,25 . Karena nilai climatic factor jaringan di atas laut lebih besar dari pada jaringan di pegunungan, maka nilai $\mathrm{C}$ factor yang dihasilkan lebih besar yang akibatnya nilai unavailability lebih besar dari pada jaringan di pegunungan. Sehingga availability yang didapatkan pada jaringan di laut lebih kecil dari pada availability yang didapatkan jaringan di pegunungan.

4. Semakin besar nilai unavailability yang dihasilkan, maka peningkatan availability yang didapatkan setelah optimasi juga semakin meningkat. Seperti pada jaringan pertama link hop pertama yang mendapatkan unavailability terbesar yaitu $1,9104611 \%$ mengalami peningkatan availability terbesar yaitu 1,90892\%.

5. Semakin kecil nilai improvement factor yang didapatkan maka peningkatan availability yang didapatkan juga akan semakin menurun. Seperti pada jaringan di laut link hop pertama yang mendapatkan improvement factor terkecil yaitu 1239,48 mengalami peningkatan availability sebesar 1,90892\%. Sedangkan pada jaringan pertama link hop kedua yang mendapatkan improvement factor tersebesar yaitu 9928,35 mengalami peningkatan availability sebesar 0,013912149\%.

6. Untuk mendapatkan peningkatan availability yang signifikan dengan menggunakan teknik space diversity maka kondisi jaringan harus berada di atas perairan atau laut dan memiliki jarak antar BTS yang jauh. Kondisi jaringan harus berada di atas permukaan laut karena nilai climatic factor yang digunakan akan meningkat dan terrain rougness yang didapatkan akan kecil, sehingga nilai C factor akan meningkat. Jika nilai C factor besar, maka unavailability yang didapatkan juga akan besar. 


\section{DAFTAR PUSTAKA}

[1] Wati, Triana Haslinda Perdana. 2012. Perencanaan dan Analisis Jaringan Transmisi Microwave menggunakan Pathloss 4.0 Studi Kasus di PT. Alita Praya Mitra Jakarta Selatan. Purwokerto: Akatel Shandy Putra Purwokerto

[2] Prabangkara, Alia Sherrin Yuchintya. 2013. Analisis Pengaruh Passive Repeater Terhadap Nilai Availability Menggunakan Pathloss 5.0. Purwokerto: Akatel Shandy Putra Purwokerto.

[3] Azhar, Muhammad. 2016. Perencanaan Jaringan Transmisi Microwave Menggunakan Pathloss 5.0 Studi Kasus Di PT. X. Purwokerto: ST3 Telkom Purwokerto.

[4] Hikmaturokhman, Alfin. 2007. Diklat Kuliah Gelombang Mikro. Purwokerto: Akatel Shandy Putra Purwokerto.

[5] Mariano, Oliver R. 2012. Design software for terresterial line of sight communication system in the philiphines. Malolos City, Bulacan State: University Philipphines.

[6] Freeman, Roger, L. 1981. Telecomunication Transmission Handbook. New York. Wiley Series.

[7] Freeman, Roger, L. 1987. Radio System For Telecomunication (1-100GHz). NewYork. John Wiley and Sons.

[8] Freeman, Roger, L. 2004. Telecomunication System Engineering. New York. Wiley.

[9] Hikmaturokhman, Alfin. 2012. Klasifikasi Link Microwave. Purwokerto: Akatel Shandy Putra Purwokerto.

[10] Freeman, Roger, L. 1999. Fundamentals Of Telecomunication. New York. A John Wiley \& Sons, Inc. 